\title{
DETERMINAN PENGUNGKAPAN VARIASI PERTUMBUHAN LABA ANTAR SEGMEN
}

\author{
Natalia Christine Putri* \\ Lodovicus Lasdi \\ Universitas Katolik Widya Mandala, Jalan Dinoyo 42-44, Surabaya \\ *nataliachristinew96@gmail.com
}

\author{
Article history: \\ Received May 2, 2020 \\ Revised June 19, 2020 \\ Accepted July 4, 2020
}

A R T I C L E I N F O

Key words:

Agency Cost, Proprietary Cost, Financing Incentives, Strategic Revelation

DOI:

https://doi.org/10.33508/jako.v12i2.2497

\begin{abstract}
A B S T R A C T
The results of previous studies regarding the determinants of strategic revelation of differences in segmen earnings growth are still not consistent. This study aims to examine and analyze the factors that are determinants of strategic revelation of differences in segmen earnings growth. These factors are proprietary costs, agency costs, and financing incentives. Tests of 136 year samples using multiple linear regression show that proprietary cost tend to increase the strategic revelation of differences in segmen earnings growth. Agency cost is proven to have no effect on the strategic revelation of differences in segmen earnings growth. And financing incentives are proven to have a negative effect on the strategic revelation of differences in segmen earnings growth. The results of this study have the implication that firstly, management does not realize the losses caused by competitors. Thereby increasing the level of strategic revelation of differences in segmen earnings growth. Secondly, there is no agency conflict that can affect the level of strategic revelation of differences in segmen earnings growth. And thirdly, management dares to take risks by providing high financial incentives to obtain financing funds but do not reduce information on variations in profit growth between segments.
\end{abstract}

\begin{abstract}
A B S T R A K
Hasil penelitian-penelitian terdahulu mengenai determinan pengungkapan variasi pertumbuhan laba antar segmen masih belum konsisten. Penelitian ini bertujuan untuk menguji dan menganalisis faktor-faktor yang menjadi determinan pengungkapan variasi pertumbuhan laba. Faktor-faktor tersebut adalah proprietary cost, agency cost, dan financing incentivess. Pengujian terhadap 136 sampel tahun dengan menggunakan regresi linier majemuk menunjukkan bahwa proprietary cost meningkatkan pengungkapan variasi pertumbuhan laba antar segmen. Agency cost terbukti tidak berpengaruh terhadap pengungkapan variasi pertumbuhan laba antar segmen. Dan financing incentivess terbukti berpengaruh negatif pengungkapan variasi pertumbuhan laba antar segmen. Hasil penelitian ini mempunyai implikasi bahwa pertama, manajemen tidak menyadari adanya kerugian yang diakibatkan oleh pesaing, sehingga tidak mengurangi tingkat pengungkapan variasi pertumbuhan antar segmen. Kedua, tidak terjadi konflik keagenan yang dapat mempengaruhi tingkat pengngkapan variasi pertumbuhan laba antar segmen. Dan ketiga, manajemen berani mengambil risiko dengan memberikan insentif keuangan tinggi untuk mendapatkan dana pembiayaan namun tidak mengurangi informasi variasi pertumbuhan laba antar segmen.
\end{abstract}

\section{PENDAHULUAN}

Dalam era globalisasi saat ini, teknologi berperan penting dalam kehidupan masyarakat seperti banyaknya media online yang tentunya dapat membuat proses belanja menjadi lebih cepat dan mudah, sehingga terjadi perubahan gaya hidup masyarakat yang lebih bersifat konsumtif. Masyarakat menjadi hedonis, lebih mengutamakan keinginan dibandingkan kebutuhan. Perubahan 
perilaku masyarakat tersebut menyebabkan adanya perubahan tren yang cepat, sehingga perusahaanperusahaan dituntut untuk dapat mengikuti perkembangan tren yang ada dalam masyarakat. Salah satu cara yang dapat dilakukan oleh perusahaan untuk dapat menyesuaikan produkproduknya dengan tren yang ada di masyarakat adalah dengan strategi diversifikasi (Lupitasari, 2012).

Strategi diversifikasi berasal dari bahasa inggris "diverse" yang memiliki makna adanya variasi dalam produk atau jasa yang disediakan oleh perusahaan. Perusahaan melakukan strategi diversifikasi karena berbagai alasan seperti ingin memaksimalkan kapasitas sumber daya perusahaan, membagi risiko bisnis, ataupun untuk meningkatkan kinerja perusahaan (Kabeyi, 2018). Menurut Eurekia dan Favourate (2014) perusahaan akan memilih untuk melakukan strategi diversifikasi saat mereka merasa tidak pasti akan aliran kas perusahaan dimasa depan. Hal tersebut juga didukung oleh Turner (2005) yang menyatakan bahwa ketika bisnis perusahaan tidak lagi mengalami peningkatan penjualan dan keuntungan, maka perusahaan harus melakukan strategi diversifikasi untuk dapat bertahan, seperti yang dilakukan oleh PT. Unilever Indonesia Tbk dimana pada tahun 2018 menjual produk baru yaitu sambal. PT. Unilever Indonesia Tbk memutuskan untuk melakukan strategi diversifikasi karena pada semester I tahun 2018 mengalami penurunan laba bersih sebesar 2,59\% (Bosnia, 2018).

Saat ini perusahaan akan semakin menyadari pentingnya melakukan strategi diversifikasi karena adanya perkembangan teknologi yang pesat, sehingga perusahaan harus dapat menyesuaikan produk atau jasa yang mereka tawarkan sesuai dengan perkembangan teknologi yang ada (Lupitasari, 2012). Contoh perusahaan yang sedang mengandalkan keunggulan teknologi adalah Grab dan Gojek dimana kedua perusahaan tersebut menawarkan jasa layanan online yang dapat dengan mudah menjangkau semua kalangan konsumen, sehingga meskipun baru berdiri namun mereka mampu mengalahkan perusahaan besar seperti Blue Bird yang belum memiliki keunggulan teknologi. Persaingan jasa layanan online tersebut membuat perusahaan Blue Bird mengalami penurunan harga saham sebanyak $25 \%$ pada tahun 2018 (Lupitasari, 2018).

Perusahaan dapat melakukan 2 jenis strategi diversifikasi yaitu strategi diversifikasi terkait (related) dan tidak terkait (unrelated) (Tarida, 2012). Perusahaan dapat melakukan strategi diversifikasi terkait dengan meyediakan barang atau jasa yang terkait dengan produk atau jasa perusahaan sebelumnya, sebaliknya perusahaan dapat melakukan strategi diversifikasi tidak terkait dengan menyediakan produk atau jasa yang tidak terakit dengan produk atau jasa perusahaan sebelumnya (Iqbal, Hameed, dan Qadeer, 2012).

Menurut Eukeria dan Favourate (2014) perusahaan melakukan strategi diversifikasi terkait untuk meningkatkan nilai pemegang saham karena perusahaan sudah memiliki kepercayaan konsumen dalam jenis usaha tersebut, sehingga perusahaan dapat meyakinkan pemegang saham bahwa produk atau jasa baru yang mereka keluarkan akan diterima dengan baik oleh masyarakat. Selain untuk meningkatkan nilai pemegang saham, perusahaan yang memilih untuk melakukan strategi diversifikasi terkait memiliki tujuan untuk dapat memiliki cost advantage dibandingkan pesaingnya, seperti yang dilakukan oleh PT. Indofood Sukses Makmur Tbk yang menyediakan produk tepung ketika mereka juga menjual produk mie instan, sehingga tentunya produk mie instan PT Indofood Sukses Makmur Tbk memiliki cost advantage dibandingkan dengan produk pesaing perusahaan lainnya (Eukeria dan Favourate, 2014).

Sebaliknya, perusahaan yang melakukan strategi diversifikasi tidak terkait dikarenakan perusahaan berada dalam lingkungan bisnis yang sudah tidak lagi bertumbuh, sehingga perusahaan harus menyediakan produk atau jasa baru yang tidak terkait dengan produk atau jasa perusahaan sebelumnya, agar perusahaan dapat bertahan. Perusahaan yang memilih untuk melakukan strategi diversifikasi tidak terkait umumnya akan menyediakan produk atau jasa baru sesuai dengan tren yang ada, sehingga perusahaan dapat bertahan. Strategi diversifikasi terkait maupun tidak terkait akan menimbulkan adanya segmen-segmen operasi. Segmen operasi ini akan mempunyai kinerja yang bervariasi. Oleh karena itu, informasi segmen-segmen operasi suatu perusahaan penting untuk diungkapkan kepada investor. Investor perlu mengetahui capaian kinerja masing-masing segmen operasi di dalam perusahaan.

Menurut Fatmawati dan Pratiwi (2018) investor akan menggunakan informasi segmen yang disampaikan oleh perusahaan untuk dapat membuat keputusan bisnis. Investor dapat membuat keputusan bisnis lebih mudah melalui informasi segmen karena dengan adanya informasi segmen maka investor dapat mengetahui bagaimana masing-masing risiko bisnis yang dihadapi oleh masing-masing segmen, sehingga keputusan bisnis 
yang diambil oleh investor akan lebih tepat. Masing-masing segmen operasi dalam perusahaan tentunya memiliki kinerja yang bervariasi, sehingga laba yang diperoleh akan bervariasi pula. Investor tentu menginginkan laporan keuangan perusahaan selengkap mungkin termasuk informasi variasi pertumbuhan laba antar segmen operasi didalam perusahaan (Fatmawati dan Pratiwi , 2018).

Pengungkapan variasi pertumbuhan laba antar segmen merupakan perbedaan laba antar segmen operasi di dalam perusahaan yang disebabkan oleh perbedaan kinerja masing-masing segmen operasi tersebut (Afrianuh, 2016). Pengungkapan variasi pertumbuhan laba antar segmen menunjukkan adanya konflik keagenan antara manajemen dengan investor. Bagi manajemen, pengungkapan variasi pertumbuhan laba antar segmen rendah (tinggi) maka menunjukkan adanya penggunaan sumber daya perusahaan secara optimal (belum optimal). Optimalisasi (belum optimalnya) penggunaan sumber daya mengindikasikan kinerja manajemen tinggi (rendah). Bagi investor, informasi yang lengkap akan mendukung pengambilan keputusan investasinya. Untuk mengatasi konflik keagenan tersebut, investor menuntut informasi mengenai pertumbuhan laba masing-masing segmen. Informasi variasi pertumbuhan laba antar segmen secara lengkap dapat mendukung investor dalam pengambilan keputusan investasi secara tepat. Apa yang menjadi determinan pengungkapan variasi pertumbuhan laba antar segmen? Beberapa penelitian terdahulu menunjukkan bahwa ada tiga faktor yang menjadi determinan, yaitu proprietary cost, agency cost, dan financing incentives (Wang, dkk., 2011; Bestari dan Siregar, 2012; Wahyudi dan Widaningsih, 2016).

Faktor pertama adalah proprietary cost yaitu biaya yang harus ditanggung oleh perusahaan karena pesaing perusahaan menggunakan informasi keuangan perusahaan dalam membuat keputusan strategis (Prencipe, 2004). Pengungkapan informasi variasi pertumbuhan laba antar segmen mengakibatkan adanya biaya, seperti biaya pembuatan laporan variasi pertumbuhan laba antar segmen, biaya auditor, serta kerugian karena informasi variasi pertumbuhan laba antar segmen perusahaan digunakan oleh pesaingnya (Bestari dan Siregar, 2012). Ketika pesaing perusahaan melihat informasi keuangan perusahaan termasuk informasi variasi pertumbuhan laba antar segmen maka pesaing perusahaan dapat mengetahui segmen operasi mana yang memiliki laba tinggi dan ren- dah, sehingga pesaing perusahaan dapat meniru strategis bisnis yang digunakan oleh perusahaan. Adanya proprietary cost yang harus ditanggung oleh perusahaan mempengaruhi pengungkapan variasi pertumbuhan laba (Wang, dkk., 2011). Proprietary cost menjadi determinan untuk mengurangi pengungkapan variasi pertumbuhan laba antar segmen secara lengkap (Prencipe, 2004).

Faktor kedua adalah agency cost yaitu biaya yang digunakan oleh investor untuk mengawasi efektivitas manajemen dalam menjalankan perusahaan (Fadah, 2010). Biaya keagenan tinggi (rendah) akan mendorong manajemen untuk meningkatkan (menurunkan) pengungkapan variasi pertumbuhan laba. Investor tidak menyukai biaya keagenan tinggi, karena risiko yang harus ditanggungnya tinggi pula. Ini mengindikasikan kinerja manajemen belum optimal dalam memanfaatkan sumber dayanya. Oleh karena itu, manajemen akan berupaya untuk meningkatkan pengungkapan variasi pertumbuhan laba antar segmen. Sebaliknya, biaya keagenan rendah mengindikasikan kinerja manajemen dalam memanfaatkan sumber dayanya secara optimal sehingga manajemen dapat mengurangi pengungkapan variasi pertumbuhan laba. Biaya keagenan menjadi salah satu faktor determinan pengungkapan variasi pertumbuhan laba antar segmensegmen operasi. Konflik kepentingan ini, mengakibatkan investor harus mengeluarkan agency cost untuk memastikan bahwa manajemen sudah mengungkapkan informasi keuangan termasuk informasi variasi pertumbuhan laba antar segmen secara lengkap (Wahyudi dan Widaningsih, 2016). Semakin tinggi (rendah) agency cost yang dikeluarkan oleh investor maka manajemen akan mengungkapkan variasi pertumbuhan laba antar segmen semakin tinggi (rendah) (Prencipe, 2004).

Faktor ketiga adalah financing incentives yaitu balas jasa yang diberikan oleh perusahaan kepada kreditor dan investor berupa bunga dan dividen (Wang, dkk., 2011). Perusahaan membagikan financing incentives dengan tujuan untuk menarik perhatian kreditor dan investor dalam berinvestasi di perusahaan. Namun ketika financing incentives yang dibagikan oleh perusahaan jauh lebih tinggi dibandingkan tahun-tahun sebelumnya, maka menunjukkan bahwa perusahaan tidak dalam kondisi baik karena perusahaan membutuhkan dana besar untuk mampu membiayai kegiatan operasinya. Oleh karena itu, semakin tinggi (rendah) financing incentives yang dibagikan oleh pe- 
rusahaan, maka pengungkapan variasi pertumbuhan laba antar segmen semakin tinggi (rendah) (Wang, dkk., 2011).

Penelitian yang dilakukan oleh Wang, dkk. (2011), Bestari dan Siregar (2012) serta Wahyudi dan Widaningsih (2016) belum mendapatkan hasil yang konsisten mengenai pengaruh proprietary cost, agency cost, dan financing incentives terhadap pengungkapan variasi pertumbuhan laba antar segmen. Oleh karena itu, penelitian ini menguji kembali determinan yaitu: proprietary cost, agency cost, dan financing incentives terhadap pengungkapan variasi pertumbuhan laba antar segmen.

Objek penelitian saat ini berbeda dengan penelitian-penelitian sebelumnya, dimana penelitian ini menggunakan perusahaan non keuangan yang terdaftar di Bursa Efek Indonesia (BEI) tahun 2015-2018 sebagai objek penelitian. Penelitian ini menggunakan perusahaan non keuangan karena perusahaan non keuangan mengalami pertumbuhan dari tahun 2015 hingga tahun 2018 yaitu tahun 2015 sebesar 4,02\% , 2016 sebesar 5,03\%, 2017 sebesar 5,07\% , dan tahun 2018 sebesar 5,17\% (Sekretariat Kabinet Indonesia, 2019).

Hasil penelitian ini menunjukkan bahwa prorietary cost meningkatkan pengungkapan variasi pertumbuhan laba. Ini berarti manajemen tidak menyadari adanya proprietary cost yang harus ditanggung oleh perusahaan dengan mengungkapkan variasi pertumbuhan laba antar segmen. Agency cost tidak berpengaruh terhadap pengungkapan variasi pertumbuhan laba. Ini mengindikasikan tidak adanya konflik keagenan antara manajemen dengan investor, sehingga tidak mempengaruhi tingkat pengungkapan variasi pertumbuhan laba antar segmen. Perusahaan publik di Indonesia mempunyai kepemilikan publik rendah, sehingga biaya keagenan dalam bentuk pengawasan oleh investor publik sangat kecil dan tidak berpengaruh secara statistik terhadap tingkat pengungkapan. Financing incentives berpengaruh negatif terhadap pengungkapan variasi pertumbuhan laba. Ini berarti perusahaan yang menjadi sampel penelitian ini mempunyai risiko tinggi. Kondisi perusahaan tidak baik, sehingga perusahaan memberikan insentif keuangan tinggi untuk mendapatkan dana. Perusahaan-perusahaan tersebut justru berupaya untuk membatasi pengungkapan variasi pertumbuhan laba.

\section{KAJIAN LITERATUR DAN PENGEMBANGAN HIPOTESIS}

Kajian Literatur

\section{Teori Keagenan}

Teori keagenan adalah teori yang menyatakan bahwa terdapat hubungan antara investor (prinsipal) dengan manajemen (agen). Investor sebagai pemilik sumber daya perusahaan akan memberikan kewenangan kepada manajemen untuk mengelola sumber daya perusahaan tersebut, sehingga antara investor dengan manajemen dapat terjadi konflik kepentingan karena manejemen sebagai pihak pengelola sumber daya perusahaan tentunya megetahui kondisi perusahaan yang sesungguhnya dan manajemen dapat memanfaatkan informasi ini untuk kepentingannya sendiri (Scott, 2015). Konflik kepentingan tidak hanya terjadi antara investor sebagai prinsipal dengan manajemen sebagai agen, namun konflik kepentingan juga dapat terjadi antara investor yang melalui manajemen bisa memperoleh keuntungan atas kreditor karena tentunya kreditor hanya bisa mengetahui informasi mengenai perusahaan berdasarkan laporan keuangan yang dibuat oleh perusahaan (Cho, 2015).

Adanya konflik kepentingan antara investor sebagai prinsipal dengan manajemen sebagai agen akan menimbulkan agency cost yang terbagi menjadi tiga komponen yakni monitoring cost, bonding cost, dan residual loss. Agency cost yang pertama yaitu monitoring cost merupakan biaya yang digunakan oleh investor untuk mengawasi kinerja manajemen dalam menjalankan perusahaan. Agency cost yang kedua yaitu biaya untuk meyakinkan bahwa segala tindakan yang dilakukan oleh manajemen untuk kepentingan prinsipal, sedangkan agency cost yang ketiga yaitu residual loss merupakan biaya yang timbul karena adanya perbedaan pada keputusan yang dibuat oleh investor dan manajemen (Jensen dan Meckling, 1976).

Perbedaan informasi yang dimiliki oleh investor dengan manajemen disebut dengan asimetri informasi. Asimetri informasi tersebut dapat terjadi karena manajemen ingin menggunakan informasi mengenai kondisi perusahaan yang sesungguhnya untuk kepentingannya sendiri yaitu untuk menutupi kinerjanya yang buruk, sehingga untuk mengatasi asimetri informasi tersebut maka investor akan menuntut manajemen untuk mengungkapkan informasi laporan keuangan selengkap mungkin agar investor dan manajemen sama-sama mengetahui kondisi perusahaan yang sesungguhnya. Hal yang sama juga terjadi pada kreditor karena kreditor sebagai pemberi dana pada perusahaan tentunya ingin mengetahui informasi keuangan perusahaan selengkap mungkin, sehingga kreditor dapat menuntut manajemen untuk memberikan informasi keuangan yang lengkap, 
termasuk informasi variasi pertumbuhan laba antar segmen (Bestari dan Siregar, 2012).

Menurut IAI (2018) dalam Pernyataan Standar Akuntansi Keuangan (PSAK) No. 1, komponen laporan keuangan yang lengkap terdiri dari laporan posisi keuangan, laporan laba rugi, laporan perubahan ekuitas, laporan arus kas, dan catatan atas laporan keuangan. Perusahaan akan menjelaskan mengenai kebijakan-kebijakan akuntansi yang digunakan beserta dengan informasi-informasi internal perusahaan termasuk informasi mengenai segmen operasi perusahaan. Informasi keuangan perusahaan termasuk informasi segmen operasi tersebut sangatlah penting untuk diungkapkan kepada investor dan kreditor agar investor dan kreditor dapat membuat keputusan investasi. Ketika informasi yang disampaikan kepada investor dan kreditor kurang lengkap maka keputusan investasi yang dibuat oleh investor dan kreditor dapat salah dan tentunya merugikan investor dan kreditor sebagai pemberi dana perusahaan. Ini mendorong manajemen untuk memberikan pengungkapan variasi pertumbuhan laba antar segmen (Bestari dan Siregar, 2012).

\section{Diversifikasi}

Diversifikasi adalah sebuah strategi bisnis yang dilakukan oleh perusahaan dengan meyediakan variasi produk atau jasa kepada kosumen (Kabeyi, 2018). Perusahaan akan merasa perlu untuk melakukan strategi diversifikasi ketika perusahaan tidak merasa pasti akan aliran kas dimasa depan, sehingga untuk mengurangi risiko bisnis yang ada maka perusahaan akan melakukan strategi diversifikasi yaitu dengan menyediakan variais produk atau jasa kepada konsumen (Lupitasari, 2012). Strategi diversifikasi dibagi menjadi dua yaitu strategi diversifikasi produk dan strategi diversifikasi pasar. Ketika perusahaan memutuskan untuk melakukan strategi diversifikasi produk maka perusahaan tidak akan bergantung pada satu jenis produk saja. Laba penjualan salah satu produk perusahaan mengalami penurunan, maka perusahaan masih dapat memperoleh laba penjualan dari produk lainnya. Strategi diversifikasi pasar dapat dilakukan oleh perusahaan dengan membuka pangsa pasar baru sehingga pangsa pasar perusahaan akan lebih besar dan hasil penjualan serta laba perusahaan akan meningkat (Kabeyi, 2018).

Perusahaan dapat melakukan strategi diversifikasi produk atau pasar yang terkait (related) ataupun yang tidak terkait (unrelated) dengan produk atau pasar yang telah dimiliki oleh perusahaan (Eurekia dan Favourate, 2014). Strategi diversifikasi produk atau pasar yang terkait dapat dilakukan oleh perusahaan dengan menambah produk atau pasar baru yang terkait dengan produk atau pasar yang telah dimiliki oleh perusahaan, sehingga ketika salah satu produk perusahaan mengalami kenaikan penjualan maka produk perusahaan yang lain juga akan mengalami kenaikan penjualan, sedangkan strategi diversifikasi produk atau pasar tidak terkait dapat dilakukan oleh perusahaan ketika produk atau pasar perusahaan tidak mengalami pertumbuhan sehingga perusahaan harus menambh produk atau pasar baru dan tidak bergantung dari hasil penjualan produk atau pasar yang lama (Iqbal, Hameed, dan Qadeer, 2012). Perusahaan melakukan strategi diversifikasi agar dapat membagi risiko yang ada. Ketika sebuah perusahaan hanya bergantung pada satu jenis produk saja, maka mereka seperti meletakkan telur-telur yang mereka punya dalam satu keranjang, sehingga ketika keranjang itu jatuh maka semua telur yang mereka punya akan hancur (David dan David, 2016). Oleh sebab itu untuk membagi risiko-risiko yang ada, maka perusahaan perlu untuk melakukan strategi diversifikasi. Dalam melakukan strategi diversifikasi perusahaan harus memastikan bahwa produk baru atau pasar baru tersebut dapat meningkatkan pendapatan perusahaan, sehingga strategi diversifikasi yang dilakukan perusahaan berhasil meningkatkan kinerja perusahaan yang dapat terlihat dari kinerja masing-masing segmen operasi yang dimiliki oleh perusahaan (Wang, dkk., 2011).

\section{Segmen Operasi}

Strategi diversifikasi produk atau pasar akan mengakibatkan perusahaan memiliki produk atau pasar lebih dari satu. Perusahaan harus melakukan segmentasi untuk dapat mengetahui produk mana yang disukai oleh masyarakat dan produk mana yang tidak disukai oleh masyarakat (Widjaya, 2017). Segmentasi dapat dilakukan oleh perusahaan dengan mengidentifikasi konsumenkonsumen perusahaan dalam masing-masing kelompok sesuai dengan kriteria (Lukitaningsih, 2013). Dari segmentasi tersebut maka akan terbentuk segmen-segmen operasi dalam perusahaan yang penting untuk diungkapkan agar investor dapat membuat keputusan investasi (Wang, dkk., 
2011).

Segmen operasi telah diatur dalam PSAK No. 5 dengan dEFinisi yaitu suatu bagian komponen dari entitas bisnis perusahaan yang mana memperoleh pendapatan dan menimbulkan beban, hasil operasinya dikaji ulang secara reguler oleh pengambil keputusan operasional mengenai pembuatan keputusan pengalokasian sumber daya pada masing- masing segmen operasi perusahaan, dan terdapat laporan keuangan yang dapat diungkapkan secara terpisah. (IAI, 2018). Pada bagian kriteria segmen yang dilaporkan dalam PSAK No. 5 dijelaskan bahwa perusahaan dapat menggabungkan informasi dua atau lebih segmen operasi apabila penggabungan tersebut telah memenuhi kriteria ekonomik serupa dan segmen tersebut serupa dalam hal (a) sifat produk dan jasa, (b) sifat dari proses produksi, (c) jenis atau kelompok pelanggan untuk produk dan jasanya, (d) metode yang dapat digunakan dalam mendistribusikan produk dan penyediaan jasanya, (e) jika dapat diterapkan sifat lingkungan pengaturan. Selain itu perusahaan harus melaporkan secara terpisah mengenai suatu segmen operasi yang telah memenuhi ambang batas kuantitatif yaitu (a) pendapatan yang dilaporkan dari segmen operasi termasuk penjualan dari pelanggan eksternal dan penjualan atau pengalihan antar segmen operasi adalah $10 \%$ atau lebih dari penggabungan pendapatan internal dan eksternal dari seluruh segmen operasi, (b) jumlah absolut dari laba rugi yang dilaporkan dari segmen operasi adalah $10 \%$ atau lebih besar dari jumlah absolut, (i) gabungan laba yang dilaporkan dari seluruh segmen operasi tidak melaporkan kerugian, dengan (ii) gabungan kerugian yang dilaporkan dari seluruh segmen operasi yang melaporkan kerugian, (c) memiliki 10\% aset atau lebih dari penggabungan aset seluruh segmen operasi. Segmen operasi yang tidak dapat memenuhi batas ambang kuantitatif masih dapat dipertimbangkan sebagai segmen dilaporkan, dan dapat diungkapakan secara terpisah, jika manajemen percaya bahwa informasi tentang segmen tersebut akan berguna bagi para pengguna laporan keuangan seperti investor dan kreditor (IAI, 2018).

Total pendapatan eksternal yang dilaporkan oleh segmen operasi kurang dari $75 \%$ dari pendapatan entitas. Ini berarti tambahan segmen operasi dapat diidentifikasi sebagai segmen dilaporkan karena segmen operasi tidak memenuhi persyaratan penggabungan segmen operasi yaitu total pendapatan eksternal yang dilaporkan oleh segmen operasi sedikitnya harus $75 \%$ dari pendapatan entitas. Saat manajemen berpendapat bahwa segmen operasi yang telah dilaporkan pada periode sebelumnya akan berkembang secara signifikan segmen operasi tersebut harus dilaporkan secara terpisah meskipun segmen operasi tersebut tidak melebih batas ambang kuantitatif, terkecuali informasi yang diperlukan oleh perusahaan untuk melaporkan informasi segmen operasi tersebut tidak tersedia (IAI, 2018).

\section{Pengukuran Segmen Operasi}

Di dalam PSAK No. 5 dijelaskan bahwa perusahaan perlu untuk mengukur laba atau rugi setiap segmen operasi untuk dapat menentukan pengalokasian sumber daya pada masing-masing aset dan kewajiban segmen operasi tersebut. Selain mengukur laba atau rugi setiap segmen operasi, perusahaan juga perlu untuk melakukan penyesuaian dan eliminasi pendapatan dan beban segmen operasi dalam menyusun laporan keuangan perusahaan agar perusahaan dapat mengukur berapa besar laba segmen operasi yang harus dilaporkan. Laba segmen operasi yang dilaporkan oleh perusahaan akan berpengaruh terhadap keputusan investasi yang dibuat oleh investor, sehingga pengukuran laba segmen operasi yang harus dilaporkan sangatlah penting (IAI, 2018). Di dalam PSAK No. 5 tahun 2018 dijelaskan bahwa terdapat enam hal yang penting untuk disampaikan dalam laporan keuangan mengenai pengukuran laba atau rugi segmen operasi serta penyesuaian dan eliminasi yang dilakukan oleh perusahaan yaitu (1) dasar akuntansi untuk setiap transaksi antar segmen operasi dilaporkan, (2) sifat dari setiap perbedaan antara pengukuran laba rugi segmen operasi dilaporkan dengan laba rugi entitas sebelum beban atau pendapatan pajak penghasilan dan operasi dihentikan, (3) sifat dari setiap perbedaan antara pengukuran atas aset segmen operasi dilaporkan dan aset entitas, (4) sifat dari setiap perbedaan antara pengukuran atas liabilitas segmen operasi dilaporkan dan liabilitas entitas, (5) sifat dari setiap perubahan dari periode lalu dalam metode pengukuran yang digunakan untuk menentukan laba rugi segmen dilaporkan dan dampak dari perubahan tersebut dalam mengukur laba rugi segmen operasi jika ada, (6) sifat dan dampak dari alokasi yang tidak simetris kepada segmen operasi dilaporkan (IAI, 2018).

\section{Pengungkapan Segmen Operasi}

Entitas mengungkapkan informasi keuangan perusahaan untuk memungkinkan para pengguna laporan keuangan dapat mengetahui aktivitas operasi perusahaan sehingga di dalam PSAK No. 5 
diatur bahwa entitas perlu untuk mengungkapkan (a) informasi umum, (b) informasi mengenai laba atau rugi segmen operasi dilaporkan, termasuk pendapatan dan beban tertentu yang termasuk dalam laba atau rugi segmen dilaporkan, aset segmen operasi, kewajiban segmen operasi, serta dasar pengukuran, (c) rekonsiliasi dari total pendapatan segmen operasi, laba atau rugi segmen operasi dilaporkan, aset segmen operasi, kewajiban segmen operasi, serta unsur material segmen operasi lainnya terhadap jumlah yang terkait dalam entitas (IAI, 2018).

\section{Pengungkapan Variasi Pertumbuhan laba Antar Seg-} men

Ketika perusahaan melakukan strategi diversivikasi maka perusahaan perlu untuk melakukan segmentasi agar perusahaan dapat lebih mudah dalam melakukan kegiatan pemasaran, sehingga perusahaan akan memiliki segmen-segmen operasi yang tentunya memiliki kinerja berbeda, sehingga menghasilkan laba yang berbeda pula. Perbedaan laba antar segmen operasi di dalam perusahaan ini lah yang disebut sebagai pengungkapan variasi pertumbuhan laba antar segmen (Bestari dan Siregar, 2012). Pengungkapan variasi pertumbuhan laba antar segmen penting untuk diungkapkan agar investor dapat mengetahui apakah kinerja manajemen sudah baik atau belum dalam mengelola sumber daya perusahaan (Afrianuh, 2016). Ketika variasi pertumbuhan laba tinggi maka menunjukkan bahwa manajemen belum memiliki kinerja yang baik karena belum mampu menggunakan sumber daya perusahaan secara maksimal, sehingga terdapat segmen operasi perusahaan yang memiliki laba jauh lebih rendah dibandingkan segmen operasi lainnya. Namun ketika variasi pertumbuhan rendah maka menunjukkan bahwa manajemen sudah memiliki kinerja yang baik karena mampu menggunakan sumber daya perusahaan secara maksimal, sehingga laba antar segmen operasi didalam perusahaan tidak memiliki perbedaan yang jauh. Untuk dapat mengukur pengungkapan variasi pertumbuhan laba antar segmen yang dilakukan oleh perusahaan (VR) maka perlu mencari pertumbuhan laba setiap segmen (GVR) terlebih dahulu.

Pertumbuhan laba setiap segmen (GVR) dapat diketahui dari laba operasi segmen perusahaan tahun ini dikurangi dengan laba operasi segmen perusahaan tahun sebelumnya, kemudian GVR paling tinggi dikurangkan dengan GVR paling rendah, sehingga dapat diketahui berapa pengungkapan variasi pertumbuhan laba antar segmen oleh perusahaan tersebut. Manajemen sebagai pengelola sumber daya perusahaan tentunya akan memiliki informasi lebih banyak mengenai kondisi perusahaan yang sesungguhnya, sehingga dapat terjadi asimetri informasi antara manajemen dengan investor. Untuk menghindari terjadinya asimetri informasi tersebut maka investor akan menuntut manajemen untuk mengungkapkan informasi keuangan termasuk informasi variasi pertumbuhan laba antar segmen selengkap mungkin agar investor dapat membuat keputusan investasi yang tepat. Determinan yang mempengaruhi tingkat pengungkapan variasi pertumbuhan laba antar segmen adalah proprietary cost, agency cost dan financing incentive (Wang, dkk., 2011; Bestari dan Siregar, 2012; Wahyudi dan Widaningsih, 2016).

\section{Proprietary Cost}

Proprietary cost yaitu biaya yang harus ditanggung oleh perusahaan karena kompetitor membuat keputusan strategis dengan menggunakan informasi keuangan termasuk informasi variasi pertumbuhan laba antar segmen yang diungkapkan oleh perusahaan (Bestari dan Siregar, 2012). Ketika perusahaan memutuskan untuk menyediakan informasi keuangan secara lengkap termasuk informasi variasi pertumbuhan laba antar segmen maka perusahaan harus menananggung poprietary cost atau biaya yang ditanggung oleh perusahaan ketika pesaing perusahaan menggunakan informasi keuangan yang diungkapkan oleh perusahaan untuk membuat keputusan bisnis (Cho, 2015).

Dengan adanya proprietary cost maka daya saing perusahaan akan mengalami penurunan, sehingga kinerja manajemen dapat dipandang buruk oleh investor. Oleh karena itu, apabila proprietary cost yang harus ditanggung oleh perusahaan terlalu tinggi, maka manajemen akan mengurangi atau membatasi pengungkapan variasi pertumbuhan laba antar segmen (Prencipe, 2004). Proprietary cost dapat diukur dengan indeks herfindahl (HHI). Indeks herfindahl dapat digunakan untuk mengetahui intensitas persaingan bisnis perusahaan. HHI dapat diukur dari kuadrat total penjualan perusahaan dibagi dengan total penjualan perusahaan jasa (Bestari dan Siregar, 2012; Wahyudi dan Widaningsih, 2016). HHI besar (kecil) menunjukkan proprietary cost rendah (tinggi). 
Agency Cost

Agency cost adalah biaya yang digunakan oleh investor untuk mengawasi bagaimana kinerja manajemen dalam menjalankan perusahaan (Fadah, 2010). Ketika segmen-segmen operasi didalam perusahaan memiliki variasi laba tinggi maka menunjukkan bahwa kinerja manajemen belum optimal dalam memaksimalkan sumber daya perusahaan. Ini berarti biaya keagenannya tinggi, sehingga manajemen akan memberikan informasi lengkap termasuk pengungkapan variasi pertumbuhan laba antar segmen. Pengungkapan variasi pertumbuhan laba antar segmen memberikan informasi yang dapat mendukung investor dalam pengambilan keputusan.

Sebaliknya, ketika segmen-segmen operasi memiliki variasi laba yang rendah maka menunjukkan bahwa kinerja manajemen sudah optimal dalam memaksimalkan sumber daya perusahaan. Ini berarti biaya keagenannya rendah, sehingga manajemen tidak perlu memberikan informasi selengkap mungkin termasuk pengungkapan variasi pertumbuhan laba antar segmen operasi. Biaya keagenan rendah mengindikasikan risiko rendah, sehingga investor kurang membutuhkan informasi keuangan termasuk informasi variasi pertumbuhan laba antar segmen secara lengkap (Prencipe, 2018). Agency cost dapat diukur menggunakan free cash flow. Free cash flow digunakan untuk mengetahui arus kas diperusahaan yang dapat dibagikan kepada kreditor dan investor setelah dikurangi dengan pengeluaran pendanaan dan pengeluaran modal. Free cash flow dapat diukur dari laba bersih dikurangi dividen ditambah depresiasi kemudian dibagi dengan total aset (Bestari dan Siregar, 2012; Wahyudi dan Widaningsih, 2016).

\section{Financing Incentives}

Financing incentive adalah balas jasa yang diberikan oleh perusahaan kepada kreditor dan investor berupa bunga dan dividen (Wang, dkk., 2011). Perusahaan akan membagikan financing incentives yang tinggi untuk menarik minat investor dan kreditor (Wang, dkk., 2011). Perusahaan yang tidak dalam kondisi baik tentu akan membagikan financing incentives yang tinggi untuk menarik minat investor dan kreditor, sehingga ketika perusahaan membagikan financing incentives yang tinggi maka investor dan kreditor akan menuntut manajemen untuk dapat mengungkapkan informasi laporan keuangan nya semakin lengkap termasuk informasi pengungkapan variasi pertumbuhan laba antar segmenagar investor dan kreditor dapat mengetahui kondisi perusahaan yang sesungguhnya dan dapat membuat keputusan investasi (Bestari dan Siregar, 2012).

Financing incentive dapat diukur dengan external financing. External financing digunakan untuk mengetahui besarnya sumber pendanaan dari kreditor dan investor yang diukur dengan rumus external equity financing (EE) ditambah total hutang jangka panjang kemudian dibagi dengan total aset. EE dapat diukur dari saham biasa ditambah saham preferen dikurangi saham treasuri dan dividen tunai (Bestari dan Siregar, 2012; Wahyudi dan Widaningsih, 2016).

\section{Ukuran Perusahaan}

Ukuran perusahaan digunakan dalam penelitian saat ini sebagai variabel kontrol agar hasil penelitian lebih optimal dan konsisten. Ukuran perusahaan merupakan besar kecilnya perusahaan yang dapat diukur melalui total penjualan, total aset, ataupun kapitalisasi pasar yang dapat dicapai oleh perusahaan (Denziana dan Monica, 2016). Dalam penelitian saat ini, ukuran perusahaan akan diukur melalui total aset perusahaan yang dapat menunjukkan berapa banyak aset yang dimiliki oleh perusahaaan untuk dapat meningkatkan kegiatan produksi dan penjualan bagi perusahaan.

Ukuran perusahaan berdasarkan total aset dapat dibagi menjadi tiga kelompok (Indriyani, 2017), yaitu: (1) Large firm yang merupakan perusahaan sudah go public dipasar modal dengan total aset minimal Rp. 200.000.000.000; (2) Medium size firm merupakan perusahaan menengah dengan total aset antara Rp. 2.000.000.000 hingga Rp. 200.000.000.000 dan (3) Small firm merupakan perusahaan kecil dengan total aset kurang dari Rp. 2.000.0000.000

Menurut Christansy dan Ardiati (2016) ukuran perusahaan yang semakin besar akan menunjukkan bahwa perusahaan memiliki transaksi yang kompleks dan daya saing yang lebih besar dalam menghasilkan kinerja keuangan yang unggul. Oleh karena itu semakin besar ukuran perusahaan maka perusahaan akan semakin memiliki kemampuan untuk memberikan informasi keuangan secara lengkap kepada stakeholder termasuk informasi mengenai pengungkapan variasi pertumbuhan laba antar segmen perusahaan (Bowrin, 2018).

\section{Pengembangan Hipotesis}

Pengaruh Proprietary Cost Terhadap Pengungkapan Variasi Pertumbuhan Laba Antar Segmen

Ketika perusahaan membuat dan mengungkapkan informasi keuangan termasuk 
informasi laba antar segmen maka akan terdapat beberapa biaya yang harus ditanggung oleh perusahaan seperti biaya pembuatan laporan keuangan termasuk informasi variasi pertumbuhan laba antar segmen, biaya auditor, dan proprietary cost yaitu biaya yang harus ditanggung oleh perusahaan ketika pesaing menggunakan informasi keuangan termasuk informasi variasi pertumbuhan laba antar segmen perusahaan dalam membuat keputusan strategis (Prencipe, 2004). Tentunya ketika manajemen mengungkapkan informasi keuangan termasuk informasi variasi laba antar segmen secara lengkap maka informasi tersebut dapat dilihat oleh pengguna laporan keuangan termasuk pesaing perusahaan, sehingga akan ada proprietary cost yang harus ditanggung oleh perusahaan (Wahyudi dan Widaningsih, 2016).

Semakin besar proprietary cost yang harus ditanggung oleh perusahaan, tentunya akan membuat daya saing perusahaan semakin menurun, sehingga kinerja manajemen akan dipandang semakin buruk oleh investor (Wang dkk, 2011). Sehingga ketika proprietary cost yang harus ditanggung oleh perusahaan besar maka manajemen akan semakin mengungkapkan informasi keuangan termasuk informasi variasi pertumbuhan laba secara tidak lengkap (Bestari dan Siregar, 2012). Dari penjelasan tersebut maka dapat disusun hipotesis sebagai berikut:

H1: Proprietary cost berpengaruh negatif terhadap pengungkapan variasi pertumbuhan laba antar segmen

Pengaruh Agency Cost Terhadap Pengungkapan Variasi Pertumbuhan Laba Antar Segmen

Masing-masing segmen operasi didalam perusahaan tentunya memiliki kinerja yang berbedabeda, sehingga laba yang diperoleh masing-masing segmen operasi didalam perusahaan pun akan berbeda (Wahyudi dan Widaningsih, 2016). Ketika variasi pertumbuhan laba antar segmen operasi didalam perusahaan tinggi maka menunjukkan bahwa manajemen belum memiliki kinerja yang baik dalam memaksimalkam sumber daya perusahaan. Sebaliknya ketika variasi pertumbuhan laba rendah maka menunjukkan bahwa manajemen sudah memiliki kinerja yang baik dalam memaksimalkan sumber daya perusahaan (Bestari dan Siregar, 2012).

Disisi lain invetor membutuhkan informasi keuangan selengkap mungkin termasuk informasi variasi pertumbuhan laba antar segmen. Menurut
Fatmawati dan Pratiwi (2018) investor akan menggunakan informasi segmen yang disampaikan oleh perusahaan untuk dapat membuat keputusan bisnis, sehingga investor harus mengeluarkan agency cost untuk memastikkan bahwa manajemen telah mengungkapkan informasi keuangan termasuk informasi variasi pertumbuhan laba antar segmen secara lengkap. Sehingga semakin besar agency cost yang dikeluarkan oleh investor maka manajemen akan mengungkapkan informasi keuangan secara lengkap termasuk informasi variasi pertumbuhan laba antar segmen (Bestari dan Siregar, 2012). Dari penjelasan tersebut maka dapat disusun hipotesis sebagai berikut:

H2: Agency cost berpengaruh positif terhadap pengungkapan variasi pertumbuhan laba antar segmen.

Pengaruh Financing Incentives Terhadap Pengungkapan Variasi Pertumbuhan Laba Antar Segmen

Perusahaan yang membagikan financing incentives yang tinggi tentu akan menarik minat investor dan kreditor, namun ketika financing incentives yang dibagikan oleh perusahaan jauh lebih tinggi dibandingkan tahun-tahun sebelumnya akan menimbulkan kecurigaan investor dan kreditor terhadap kondisi perusahaan yang sesungguhnya (Bestari dan Siregar, 2012).

Sesuai dengan teori keagenan maka ketika perusahaan tersebut berada dalam kondisi stabil akan meningkatkan pemberian financing incentives secara bertahap, namun ketika perusahaan meningkatkan pemberian financing incentives jauh lebih tinggi dibandingkan tahun-tahun sebelumnya maka dapat menunjukkan bahwa kondisi perusahaan tersebut tidak baik karena perusahaan sedang membutuhkan dana besar untuk membiayai kegiatan operasinya, sehingga perusahaan memberikan financing incentives yang tinggi untuk dapat menarik minat investor dan kreditor (Wang dkk, 2011). Untuk mengatasi konflik kepentingan tersebut maka ketika perusahaan membagikan financing incentives yang tinggi, investor dan kreditor akan menuntut manajemen untuk mengungkapkan informasi keuangan perusahaan selengkap mungkin termasuk informasi pengungkapan variasi pertumbuhan laba antar segmen untuk dapat mengetahui kondisi perusahaan yang sesungguhnya karena penting bagi investor dan kreditor untuk mengetahui bagaimana kondisi perusahaan yang sesungguhnya agar mereka dapat memutuskan untuk berinvestasi didalam perusahaan atau tidak 
berinvestasi didalam perusahaan tersebut (Wahyudi dan Widaningsih, 2016). Oleh karena itu semakin tinggi financing incentives yang diberikan oleh perusahaan maka manajemen akan mengungkapkan informasi keuangan teramasuk informasi laba antar segmen perusahaan semakin lengkap (Bestari dan Siregar, 2012). Dari penjelasan tersebut maka dapat disusun hipotesis sebagai berikut

H3: Financing incentive berpengaruh positif terhadap pengungkapan variasi pertumbuhan laba antar segmen.

\section{METODE PENELITIAN}

Jenis data yang digunakan adalah data kuantitatif berupa laporan keuangan perusahaan non keuangan yang terdaftar di BEI periode 2015-2018. Sumber data laporan keuangan diperoleh dari website BEI (www.idx.co.id), berupa data sekunder. Metode pengumpulan data yang digunakan adalah metode dokumentasi. Dokumentasi dilakukan dengan mengumpulkan laporan keuangan perusahaan non keuangan yang terdaftar di BEI selama periode 2015-2018.

\section{Populasi dan Sampel Penelitian}

Populasi penelitian adalah perusahaan non keuangan yang terdaftar di BEI. Dari populasi tersebut akan diambil sampel dengan menggunakan metode purposive sampling dengan kriteria sebagai berikut:

Tabel 1. Pemilihan Sampel Penelitian

\begin{tabular}{|l|l|c|}
\hline No & Kriteria & Jumlah \\
\hline 1. & $\begin{array}{l}\text { Jumlah perusahaan non keu- } \\
\text { angan yang terdaftar di Bursa } \\
\text { Efek Indonesia selama 2015-2018 }\end{array}$ & 288 \\
\hline 2. & $\begin{array}{l}\text { Perusahaan non keuangan yang } \\
\text { menerbitkan laporan tahunan } \\
\text { secara berturut-turut di BEI } \\
\text { periode 2015-2018 }\end{array}$ & $(33)$ \\
\hline 3. & $\begin{array}{l}\text { Perusahaan non keuangan mul- } \\
\text { tisegmen yang mengungkapkan } \\
\text { laba antar segmen operasi pada } \\
\text { laporan tahunan nya. }\end{array}$ & $(221)$ \\
\hline 4. & $\begin{array}{l}\text { Jumlah perusahaan non keu- } \\
\text { angan yang memenuhi kriteria } \\
\text { sampel }\end{array}$ & 34 \\
\hline 5. & Jumlah periode penelitian & 4 tahun \\
\hline 6. & Jumlah sampel akhir penelitian & 136 \\
\hline
\end{tabular}

Sumber: Data diolah

\section{Variabel Penelitian}

Penelitian saat ini menggunakan variabel dependen pengungkapan variasi pertumbuhan laba antar segmendan 3 variabel independen yaitu proprietary cost, agency cost, dan financing incentives. Definisi operasional serta pengukuran dari masingmasing variabel adalah sebagai berikut:

Pengungkapan Variasi pPertumbuhan Laba Antar Seg$\operatorname{men}(V R)$

Pengungkapan variasi pertumbuhan laba antar segmen(VR) adalah masing- masing pertumbuhan laba antar segmen yang diungkapkan oleh perusahaan (Bestari dan Siregar, 2012). Untuk dapat mengetahui pengungkapan variasi pertumbuhan laba antar segmen (VR) maka perlu menghitung pertumbuhan laba setiap segmen (GVR) terlebih dahulu dengan rumus sebagai berikut:

$\mathrm{GVR}=\quad$ Laba segmen $\mathrm{t}-$ Laba segmen $\mathrm{t}-1$

Total penjualan bersih segmen $\mathrm{t}-1$

Selanjutnya dihitung pengungkapan variasi pertumbuhan laba antar segmen (VR) dengan rumus sebagai berikut (Bestari dan Siregar, 2012):

$\mathrm{VR}=\mathrm{GVR}$ segmen paling tinggi - GVR segmen paling rendah

Semakin besar pengungkapan variasi pertumbuhan laba antar segmen (VR) maka menunjukkan bahwa manajemen semakin lengkap dalam mengungkapkan informasi keuangan perusahaan termasuk informasi variasi pertumbuhan laba antar segmen. Nilai VR yang besar menunjukkan bahwa semakin banyak segmen yang diungkapkan oleh perusahaan, sehingga variasi laba antar segmen juga semakin besar.

\section{Proprietary Cost (HHI)}

Proprietary cost merupakan biaya yang timbul karena kompetitor menggunakan informasi privat perusahaan dalam pengungkapan informasi keuangan untuk membuat keputusan strategis (Bestari dan Siregar, 2012). Proprietary cost diproksikan oleh Indeks Herfindahl (HHI) yang dapat diukur dengan rumus sebagai berikut:

$$
\mathrm{HHI}=\frac{(\text { Total penjualan perusahaan })^{2}}{\left(\begin{array}{l}
\text { (Total penjualan perusahaan non } \\
\text { keuangan })^{2}
\end{array}\right.}
$$

Agency Cost (FCF)

Agensy cost adalah biaya yang dikeluarkan oleh pemegang saham untuk mengawasi kinerja manajemen (Fadah, 2010). Agency cost diproksikan dengan free cash flow yang diukur dengan menggunakan rumus sebagai berikut (Bestari dan Siregar, 2012): 
FCF $=\underline{\text { Laba bersih }- \text { Dividen }+ \text { Depresiasi }}$ Total aset

Financing Incentives (EF)

Financing incentives yaitu suatu balas jasa atas modal yang telah diberikan oleh kreditor dan investor untuk meningkatkan kinerja perusahaan yang dapat dilakukan dengan membayar bunga dan membagikan dividen (Bestari dan Siregar, 2012). Untuk dapat mencari financing incentives maka perlu mencari external equity financing (EE) terlebih dahulu dengan cara saham biasa ditambah saham preferen dikurangi saham treasuri dikurangi dividen tunai kemudian dibagi total aset. Setelah diketahui external equity financing (EE) maka selanjutnya dapat dicari financing incentives (EF) dengan rumus sebagai berikut:

$\mathrm{EF}=\frac{\mathrm{EE}+\text { Total hutang jangka panjang }}{\text { Total aset }}$

Ukuran Perusahaan (SIZE)

merupakan nilai yang dapat menunjukkan besar kecilnya ukuran perusahaan dengan melihat dari total penjualan, total aset, maupun kapitalisasi pasar yang dapat dicapai (Denziana dan Monica, 2016). Ukuran perusahaan dapat diukur dengan menggunakan rumus sebagai berikut (Bestari dan Siregar, 2012):

$$
\text { Ukuran perusahaan }=\text { Ln }(\text { Total Aset })
$$

\section{HASIL DAN PEMBAHASAN}

Objek penelitian saat ini adalah perusahaan non keuangan yang terdaftar di Bursa EFek Indonesia (BEI) periode 2015-2018. Berdasarkan kriteria purposive sampling yang telah ditetapkan maka dari 288 perusahaan non keuangan yang terdaftar di Bursa EFek Indonesia periode 2015-2018, terdapat 34 perusahaan yang menjadi sampel penelitian berdasarkan kriteria purposive sampling yaitu, 1) Terdapat 33 perusahaan non keuangan yang tidak menerbitkan laporan tahunan secara berturut-turut di BEI periode 2015-2018 dan 2) Terdapat 221 perusahaan non keuangan multisegmen yang tidak mengungkapkan laba antar segmen operasi pada laporan keuangannya.

Tabel 2. Hasil Uji Normalitas

\begin{tabular}{|l|l|}
\hline Signifikansi & Keterangan \\
\hline 0,250 & Residual terdistribusi normal \\
\hline
\end{tabular}

Sumber: Data diolah
Hasil uji normalitas pada tabel 2 menunjukkan bahwa data sampel perusahaan non keuangan untuk penelitian saat ini telah terdistribusi normal karena memiliki nilai signifikansi sebesar 0,25 dimana nilai signifikansi tersebut lebih besar dari 0,05 .

Tabel 3. Hasil Uji Heteroskedastisitas

\begin{tabular}{|l|l|l|}
\hline Variabel & Signifikansi & Keterangan \\
\hline HHI & 0,439 & Homokedastisitas \\
\hline FCF & 0,102 & Homokedastisitas \\
\hline EF & 0,193 & Homokedastisitas \\
\hline SIZE & 0,384 & Homokedastisitas \\
\hline
\end{tabular}

Sumber: Data diolah

Hasil uji heterokedastisitas pada tabel 3 menunjukkan bahwa nilai signifikansi yang dimiliki oleh seluruh variabel lebih dari 0,05. Oleh karena itu dapat disimpulkan bahwa data sampel perusahaan non keangan untuk penelitian saat ini hanya memiliki homokedastisitas dan tidak terdapat heteroskedastisitas.

Tabel 4. Hasil Uji Multikolinieritas

\begin{tabular}{|l|l|l|l|}
\hline Variabel & Tolerance & VIF & Keterangan \\
\hline HHI & 0,822 & 1,216 & $\begin{array}{l}\text { Bebas Multikoloni- } \\
\text { eritas }\end{array}$ \\
\hline FCF & 0,977 & 1,023 & $\begin{array}{l}\text { Bebas Multikoloni- } \\
\text { eritas }\end{array}$ \\
\hline EF & 0,940 & 1,063 & $\begin{array}{l}\text { Bebas Multikoloni- } \\
\text { eritas }\end{array}$ \\
\hline SIZE & 0,877 & 1,141 & $\begin{array}{l}\text { Bebas Multikoloni- } \\
\text { eritas }\end{array}$ \\
\hline
\end{tabular}

Sumber: Data diolah

Hasil uji multikolinieritas pada tabel 4 menunjukkan bahwa nilai tolerance yang dimiliki oleh semua variabel independen penelitian saat ini melebihi 0,10, sehingga tidak terdapat korelasi antar variabel independen yang nilainya lebih dari 95\%. Hasil tersebut juga didikung dengan nilai VIF semua variabel independen penelitian saat ini yang tidak lebih dari 10, sehingga dapat disimpulkan bahwa tidak terjadi multikolonieritas antar variavel independen pada penelitian saat ini.

Tabel 5. Hasil Uji Autokorelasi

\begin{tabular}{|l|l|}
\hline Durbin-Watson & Keterangan \\
\hline 1,958 & Tidak terjadi autokorelasi \\
\hline
\end{tabular}

Sumber: Data diolah

Hasil uji autokorelasi pada tabel 5 menunjukkan bahwa nilai Durbin-Watson (DW) test adalah 1,958. Nilai DW tersebut lebih besar dari batas atas 
(dU) yaitu 1,7808 dan juga tidak melebihi 2,042 (4dU). Batas atas tersebut ditentukkan berdasarkan jumlah sampel perusahaan non keuangan yaitu 136 dengan jumlah variabel independen penelitian saat ini yaitu 3 dan variabel kontrol $1(n=136$ dan $k=4)$.

Tabel 6. Hasil Uji Koefisien Determinasi

\begin{tabular}{|l|l|l|l|}
\hline$R$ & R Square & $\begin{array}{l}\text { Adjusted } \\
\text { Square }\end{array}$ & $\begin{array}{l}\text { Std. Error of } \\
\text { the Estimate }\end{array}$ \\
\hline 0,266 & 0,071 & 0,043 & 0,69235 \\
\hline
\end{tabular}

Sumber: Data diolah

Hasil uji koefisien determinasi pada tabel 6 menunjukkan nilai R Square sebesar 7\% yang memiliki arti bahwa $7 \%$ variabel dependen (VR) dapat dijelaskan oleh variabel independen (HHI, FCF, GR) yang digunakan dalam penelitian saat ini, sedangkan $93 \%$ sisanya dapat dijelaskan oleh variabel lain di luar penelitian saat ini.

Tabel 7. Hasil Uji F

\begin{tabular}{|c|c|}
\hline F & Sig \\
\hline 2,498 & 0,046 \\
\hline
\end{tabular}

Sumber: Data diolah

Hasil uji $\mathrm{F}$ pada tabel 7 menunjukkan bahwa nilai probabilitas $\mathrm{F}$ adalah 0,046 dimana nilai tersebut lebih kecil dari 0,05 , sehingga menunjukkan bahwa H0 ditolak dan H1 diterima. Oleh karena itu, dapat ditarik kesimpulan bahwa model regresi dalam penelitian saat ini dapat digunakan untuk menganalisis pengaruh dari proprietary cost, agency cost, dan financing incentives terhadap pengungkapan variasi pertumbuhan laba antar segmen dengan ukuran perusahaan sebagai variabel kontrol.

Tabel 8: Hasil Uji t

\begin{tabular}{|l|l|l|l|l|}
\hline \multirow{2}{*}{ Variabel } & \multicolumn{2}{|l|}{$\begin{array}{l}\text { Unstandardized } \\
\text { Coeficients }\end{array}$} & \multirow{2}{*}{$\mathrm{t}$} & \multirow{2}{*}{ Sig } \\
\cline { 2 - 4 } & $\mathrm{B}$ & Std. Error & & \\
\hline (Constant) & $-2,418$ & 0,584 & $-4,144$ & 0 \\
\hline HHI & $-1,866$ & 0,862 & $-2,165$ & 0,032 \\
\hline FCF & 0,284 & 0,714 & 0,397 & 0,692 \\
\hline EF & $-0,543$ & 0,269 & $-2,020$ & 0,045 \\
\hline SIZE & 0,046 & 0,020 & 2,271 & 0,025 \\
\hline
\end{tabular}

Sumber: Data diolah

Berdasarkan tabel 8 maka dapat dihasilkan model persamaan regresi sebagai berikut:

$\mathrm{VR}=-2,418-1,866 \mathrm{HHI}+0284 \mathrm{FCF}-0,543 \mathrm{EF}+$ $0,046 \mathrm{SIZE}+\mathrm{E}$

Penjelasan dari persamaan regresi dan hasil yang didapatkan adalah sebagai berikut:

1. E (konstanta) bernilai $-2,418$ jika proprietary cost (HHI), agency cost (FCF), financing incentives (EF), dan ukuran perusahaan (SIZE) tidak memberikan pengaruh terhadap pengungkapan variasi pertumbuhan laba antar segmen (VR) atau bernilai nol.

2. Koefisien regresi untuk HHI bernilai $-1,866$ yang memiliki arti bahwa ketika proprietary cost naik sebesar $1 \%$ maka pengungkapan variasi pertumbuhan laba antar segmen akan turun sebesar -1,866.

3. Koefisien regresi untuk FCF bernilai 0,284 yang memiliki arti bahwa ketika agency cost naik sebesar $1 \%$ maka pengungkapan variasi pertumbuhan laba antar segmen akan naik sebesar 0,284.

4. Koefisien regresi untuk EF bernilai $-0,543$ yang memiliki arti bahwa ketika financing incentives naik sebesar $1 \%$ maka pengungkapan variasi pertumbuhan laba antar segmen akan turun sebesar -0,543.

5. Koefisien regresi untuk SIZE bernilai 0,046 yang memiliki arti bahwa ketika ukuran perusahaan naik sebesar $1 \%$ maka pengungkapan variasi pertumbuhan laba antar segmen akan naik sebesar 0,046 .

Penjelasan dari hasil uji t pada tabel 10 dapat dijelaskan sebagai berikut:

1. Proprietary Cost

Variabel proprietary cost memiliki t sebesar -2,165 dengan nilai signifikansi $0,032 \leq 0,05$ yang menunjukkan bahwa variabel independen proprietary cost (HHI) berpengaruh negatif signifikan terhadap variabel dependen pengungkapan variasi pertumbuhan laba antar segmen. Oleh karena itu H1 yang menyatakan bahwa variabel proprietary cost berpengaruh negatif terhadap pengungkapan variasi pertumbuhan laba antar segmen ditolak.

2. Agency Cost

Variabel agency cost memiliki $\mathrm{t}$ sebesar 0,397 dengan nilai signifikansi 0,692 yang menunjukkan bahwa variabel independen agency cost (FCF) tidak berpengaruh signifikan terhadap variabel dependen pengungkapan variasi pertumbuhan laba antar segmen. Oleh karena itu, $\mathrm{H} 2$ yang menyatakan bahwa agency cost (FCF) berpengaruh positif terhadap pengungkapan variasi pertumbuhan laba antar segmen ditolak.

3. Financing Incentives

Variabel financing incentives memiliki t sebesar 2,020 dengan nilai signifikansi 0,045 $\leq 0,05$ yang menunjukkan bahwa variabel independen $f i$ - 
nancing incentives (EF) berpengaruh negatif signifikan terhadap variabel dependen pengungkapan variasi pertumbuhan laba antar segmen. Oleh karena itu H3 yang menyatakan bahwa financing incentives berpengaruh positif terhadap pengungkapan variasi pertumbuhan laba antar segmen ditolak.

\section{Pembahasan}

Dari hasil analisis data diatas maka dapat diperoleh penjelasan sebagai berikut:

Pengaruh proprietary cost terhadap pengungkapan variasi pertumbuhan laba antar segmen

Hipotesis yang menyatakan bahwa variabel independen proprietary cost berpengaruh negatif terhadap variabel dependen pengungkapan variasi pertumbuhan laba antar segmen ditolak. Perusahaan tidak menyadari adanya proprietary cost, sehingga manajemen tetap meningkatkan pengungkapan variasi pertumbuhan laba. Perusahaan memutuskan untuk mengungkapkan informasi keuangan secara lengkap termasuk informasi variasi pertumbuhan laba antar segmen. Proprietary cost atau biaya yang harus ditanggung oleh perusahaan ketika pesaing perusahaan melihat laporan segmen yang diungkapkan oleh perusahaan atau kerugian karena pesaing berupaya meniru produk perusahaan yang paling laris, justru meningkatkan pengungkapan informasi keuangan secara lengkap.

Manajemen tentunya sangat memperhatikan proprietary cost tersebut karena semakin besar proprietary cost yang harus ditanggung oleh perusahaan maka daya saing perusahaan akan mengalami penurunan sehingga kinerja manajemen tersebut akan dinilai buruk oleh investor (Cho, 2015). Namun hal tersebut justru akan meningkatkan pengungkapan informasi keuangan secara lengkap.

Hasil pengujian ini tidak mendukung hasil penelitian Wahyudi dan Widaningsih (2016) yang menunjukkan bahwa proprietary cost berpengaruh negatif terhadap pengungkapan variasi pertumbuhan laba antar segmen. Oleh karena itu semakin tinggi proprietary cost yang harus ditanggung oleh perusahaan maka manajemen akan mengungkapkan informasi keuangan termasuk informasi variasi pertumbuhan laba antar segmen secara tidak lengkap (Wahyudi dan Widaningsih, 2016).

Pengaruh agency cost terhadap pengungkapan variasi pertumbuhan laba antar segmen

Hipotesis yang menyatakan bahwa agency cost berpengaruh positif terhadap pengungkapan variasi pertumbuhan laba antar segmen ditolak. Ketika variasi pertumbuhan laba antar segmen tinggi maka menunjukkan bahwa kinerja manajemen belum baik karena belum mampu memaksimalkan sumber daya perusahaan, sebaliknya ketika variasi pertumbuhan laba antar segmen operasi didalam perusahaan rendah maka menunjukkan bahwa kinerja manajemen sudah baik karena mampu memaksimalkan sumber daya perusahaan (Prencipe, 2004). Namun disisi investor tentunya membutuhkan informasi keuangan secara lengkap termasuk informasi variasi pertumbuhan laba antar segmen agar investor dapat membuat keputusan bisnis yang tepat dan sesuai dengan kondisi perusahaan. Sehingga investor akan mengeluarkan agency cost untuk memastikkan bahwa manajemen telah mengungkapkan informasi keuangan secara lengkap, termasuk informasi variasi pertumbuhan laba antar segmen (Cho, 2015).

Hasil penelitian ini menyatakan bahwa agency cost tidak berpengaruh terhadap pengungkapan variasi pertumbuhan laba antar segmen. Ini mengindikasikan bahwa, pertama, biaya pengawasan oleh publik yang menjadi investor sangat kecil, sehingga tidak mempengaruhi pengungkapan informasi variasi laba antar segmen. Kedua, diduga karena manajemen lebih memperhatikan pesaing perusahaan dalam mengungkapkan informasi keuangan termasuk informasi variasi pertumbuhan laba antar segmen. Hasil penelitian ini sejalan dengan hasil penelitian Wang dkk. (2011) serta Bestari dan Siregar (2012) yang menunjukkan bahwa agency cost tidak berpengaruh terhadap pengungkapan variasi pertumbuhan laba antar segmen. Sehingga besar atau kecilnya agency cost yang dikeluarkan oleh investor, tidak akan berdampak pada pengungkapan informasi keuangan termasuk informasi variasi pertumbuhan laba antar segmen perusahaan (Bestari dan Siregar, 2012).

Pengaruh financing incentives terhadap pengungkapan variasi pertumbuhan laba antar segmen

Hipotesis yang menyatakan bahwa financing incentives berpengaruh positif terhadap pengungkapan variasi pertumbuhan laba antar segmen ditolak. Hasil analisis menunjukkan bahwa financing incentives berpengaruh negatif signfikan terhadap pengungkapan variasi pertumbuhan laba antar segmen perusahaan. Hasil penelitian ini tidak mengkonfirmasi penelitian Wahyudi dan Widan- 
ingsih (2016) yang menunjukkan bahwa financing incentives berpengaruh positif terhadap pengungkapan variasi pertumbuhan laba antar segmen, namun hasil penelitian saat ini mengkonfirmasi penelitian Bestari dan Siregar (2012) yang menunjukkan bahwa financing incentives berpengaruh negatif signifikan terhadap pengungkapan variasi pertumbuhan laba antar segmen karena semakin besar financing incentives yang diberikan oleh perusahaan maka menunjukkan bahwa perusahaan tidak dalam kondisi baik, sehingga manajemen dalam mengungkapkan informasi keuangan nya termasuk informasi pengungkapan variasi pertumbuhan laba antar segmen semakin tidak lengkap.

Financing incentives adalah suatu balas jasa yang diberikan kepada kreditor dan investor untuk meningkatkan kinerja perusahaan (Wang dkk., 2011). Semakin besar financing incentives yang diberikan oleh perusahaan kepada kreditor dan investor maka menunjukkan bahwa perusahaan tidak dalam kondisi baik, sehingga manajemen tidak akan mengungkapkan informasi laporan keuangan secara lengkap termasuk informasi pengungkapan variasi pertumbuhan laba antar segmen.

Pengaruh Ukuran Perusahaan terhadap Pengungkapan Variasi Pertumbuhan Laba antar Segmen

Hasil penelitian ini menunjukkan bahwa ukuran perusahaan berpengaruh positif terhadap pengungkapan variasi pertumbuhan laba antar segmen. Ini berarti perusahaan besar (kecil) cenderung memberikan informasi keuangan lengkap (tidak lengkap) termasuk informasi variasi pertumbuhan laba antar segmen tinggi (rendah).

Perusahaan besar mempunyai sumber daya besar sehingga mampu mengeluarkan biaya yang dibutuhkan untuk melakukan pengungkapan variasi pertumbuhan laba antar segmen. Sebaliknya, perusahaan kecil tidak mempunyai cukup dana untuk mengungkapan variasi pertumbuhan laba antar segmen. Ukuran perusahaan merupakan variabel kontrol yang powerful dalam mengendalikan pengungkapan variasi pertumbuhan laba antar segmen.

\section{SIMPULAN}

Hasil analisis dan pembahasan, menyimpulkan bahwa proprietary cost cenderung meningkatkan pengungkapan variasi pertumbuhan laba antar segmen. Semakin besar proprietary cost yang harus ditanggung oleh perusahaan maka daya saing perusahaan akan semakin menurun sebagai akibat dari pesaing perusahaan yang meniru strategi bisnis perusahaan. Namun tingkat pengungkapan variasi laba antar segmen tetap tinggi. Ini mengindikasikan bahwa manajemen tidak menyadari adanya proprietary cost, sehingga tidak membatasi tingkat pengungkapan informasi keuangan termasuk informasi variasi pertumbuhan laba antar segmen secara tidak lengkap.

Agency cost tidak berpengaruh terhadap pengungkapan variasi pertumbuhan laba antar segmen. Ini mengindikasikan bahwa biaya keagenan yang dikeluarkan oleh investor sangat kecil sehingga tidak mempengaruhi pengungkapan variasi pertumbuhan laba antar segmen.

Financing incentives berpengaruh negatif signifikan terhadap pengungkapan variasi pertumbuhan laba antar segmen. Semakin besar financing incentives yang diberikan oleh perusahaan kepada kreditor dan investor, maka investor akan semakin meminta manajemen mengungkapkan informasi keuangan secara lengkap termasuk pengungkapan variasi pertumbuhan laba antar segmen.

Variabel kontrol yang digunakan dalam penelitian saat ini yaitu ukuran perusahaan berpengaruh positif terhadap pengungkapan variasi pertumbuhan laba antar segmen, sehingga semakin besar ukuran perusahaan maka perusahaan akan semakin banyak mengungkapkan informasi keuangan perusahaan termasuk pengungkapan variasi pertumbuhan laba antar segmen sebagai bentuk pertanggung jawaban kepada kreditor dan investor perusahaan. Ukuran perusahaan berpengaruh positif terhadap pengungkapan variasi pertumbuhan laba antar segmen. Implikasinya adalah perusahaan besar memberikan informasi lebih lengkap dibandingkan perusahaan kecil.

\section{REFFERENCES}

Afrianuh, M. A. (2016). Faktor-Faktor yang Mempengaruhi Pengungkapan Variasi Pertumbuhan Laba Antar Segmen pada Perusahaan Manufaktur yang Terdaftar di Bursa Efek Indonesia Tahun 2013-2015. Jurnal Bisnis dan Akuntansi, 9(1), 1-27.

Bestari, M. dan Siregar, S. V. (2012). Determinan Motif Pengungkapan Variasi Pertumbuhan Laba Antar Segmen Perusahaan Manufaktur yang Terdaftar di Indonesia, Prosiding. Simposium Nasional Akuntansi XV: Banjarmasin

Bosnia, T. (2018). Diversifikasi Usaha, Unilever Masuk Bisnis Saus Sambal. Didapat dari https://www.cnbcindonesia.com/market/201 
80928100757-17-35152/diversifikasi-usahaunilever-masuk-bisnis-saus-sambal, 10 Juni 2020, pukul 17:22 WIB.

Bowrin, A. R. (2018). Human Resources Disclosures by African and Caribbean Companies. Journal of Accounting in Emerging Economies, 8(2), 244278.

Cho, Y. J. (2015). Segment Disclosure Transparancy and Internal Capital Market Efficiency: Evidence from SFAS No. 131, Journal of Accounting Research, 53(4), 669-723.

Cristansy J. dan Ardiati, A. Y. (2016). Pengaruh Kompleksitas Perusahaan, Ukuran Perusahaan, dan Ukuran KAP Terhadap Fee Audit pada Perusahaan Manufaktur yang Terdaftar di BEI Tahun 2012-2016, MODUS, 30(2), 198211.

David, F. R. dan David, F. R. (2016). Manajemen Strategik: Suatu Pendekatan Keunggulan Bersaing (Edisi 15). Jakarta: Salemba Empat.

Denziana, A. dan Monica, W. (2016). Analisis Ukuran Perusahaan dan Profitabilitas terhadap Nilai Perusahaan (Studi Empiris pada Perusahaan yang Tergolong LQ45 di BEI Periode 2011-2014. Jurnal Akuntansi dan Keuangan, 7(2), 241-254.

Eukeria, M. dan Favourate, S. (2014). Diversification as a Corporate Strategy and Its Effect on Firm Performance: A Study of Zimbabwean Listed Conglomerate Food and Beverages Sector. International Journal of economics and Finance, 6(5), 182-195.

Fadah, I. (2010). Faktor Penentu Dividen dan Biaya Keagenan serta Pengaruhnya pada Nilai Perusahaan, Jurnal Keuangan dan Perbankan, 14(3), 391-406.

Fatmawati, D. S. dan Pratiwi, A. (2018), Segment Reporting: The Beginning of Transition Period in Indonesia, Review of Integrative Business and Economics Research, 7(3), 190-201.

Ikatan Akuntan Indonesia. (2018). Standar Akuntansi Keuangan. Jakarta: IAI.

Indriyani E., (2017), Pengaruh Ukuran Perusahaan dan Profitabilitas Terhadap Nilai Perusahaan, Akuntabilitas: Jurnal Ilmu Akuntansi, 10(2), 333-
348.

Iqbal, A., Hameed, I. dan Qadeer, M. (2012). Impact of Diversification on Firms' Performance. American Journal of Scientific Research, 80, 42-53.

Jensen, M. C. dan Meckling, W. H. (1976). Theory of The Firm: Managerial Behavior, Agency Cost, and Ownership Structure. Journal of Finance Economics, 3(4), 305-360.

Kabeyi, M. (2018). Organizational Strategic Diversification with Case Studies of Successful and Unsuccessful Diversification, Intrenational Journal of Scientific and Engineering Research, 9(9), 871-886.

Lukitaningsih, A. (2013). Peranan Segementasi Dalam Perilaku Konsumen Guna Menciptakan Iklan Yang Efektif. Jurnal Ekonomi dan Kewirausahaan, 13(1), 25-39.

Lupitasari, D. (2012). Diversifikasi Perusahaan dan Manajemen Laba. Diponegoro Journal of Accounting, 1(1), 1-12.

Prencipe, A. (2004). Proprietary Costs and Determinants of Voluntary Segment Disclosure: Evidence from Italian Listed Companies. European Accounting Review, 13(2), 319-340.

Scott, W. R. (2015). Financial Accounting Theory (7th Edition), Canada: Toronto Pearson Education Limited.

Sekretariat Kabinet Republik Indonesia. (2019). Ekonomi Indonesia Tumbuh Positif di Tengah Ketidakpastian Global. Didapat dari https://www.setneg.go.id/baca/index/ekono mi_indonesia_tumbuh_positif_di_tengah_keti dakpastian_global, 5 Januari 2020, pukul 13:21 WIB.

Tarida, Y. (2012). Strategi Diferensiasi Produk, Diversifikasi Produk, Harga Jual dan Kaitannya Terhadap Penjualan pada Industri Kerajinan Rotan di Kota Palembang. Jurnal Ekonomi Pembangunan, 10(2), 124-142.

Turner, I. (2005). Diversification: When to and When not to?. Henley Manager Update, 16(3), 17.

Wahyudi, A. D. dan Widaningsih, M. (2016). Analisis Faktor-Faktor yang Mempengaruhi Strategic revelation of differences in segmen earn- 
ings growth, Jurnal Riset Akuntansi dan Keuangan, 4 (1), 127-140.

Wang, Q., Ettredge, M., Huang Y. dan Sun, L. (2011). Strategic Revelation of Differences In Segment Earnings Growth. Journal of Accounting and Public Policy, 30(4), 383-393.

Widjaya, P. G. (2017). Analisis Segmenting, Targeting, Positioning dan Marketing Mix pada PT. Murni Jaya, AGORA,5(1), 1-8. 